\title{
Application of a degree-day model of West Nile virus transmission risk to the East Coast of the United States of America
}

\author{
Sarah K. Konrad, Scott N. Miller \\ University of Wyoming, Ecosystem Science and Management, Dept. 3354, Laramie, WY 82071, USA
}

\begin{abstract}
A geographical information systems model that identifies regions of the United States of America (USA) susceptible to West Nile virus (WNV) transmission risk is presented. This system has previously been calibrated and tested in the western USA; in this paper we use datasets of WNV-killed birds from South Carolina and Connecticut to test the model in the eastern USA. Because their response to WNV infection is highly predictable, American crows were chosen as the primary source for model calibration and testing. Where crow data are absent, other birds are shown to be an effective substitute. Model results show that the same calibrated model demonstrated to work in the western USA has the same predictive ability in the eastern USA, allowing for a continental-scale evaluation of the transmission risk of WNV at a daily time step. The calibrated model is independent of mosquito species and requires inputs of only local maximum and minimum temperatures. Of benefit to the general public and vector control districts, the model predicts the onset of seasonal transmission risk, although it is less effective at identifying the end of the transmission risk season.
\end{abstract}

Keywords: West Nile virus, mosquitoes, transmission risk, geographical information system, United States of America.

\section{Introduction}

Since its arrival in the United States of America (USA) in 1999, West Nile virus (WNV) has established itself across the country (Enserink, 2002), posing a health risk to humans and other animals. WNV is an arbovirus (Flaviviridae, Flavivirus) primarily transmitted by mosquitoes, whereas birds serve as the primary reservoir (Hayes, 1989). Temperature is a necessary and limiting factor influencing the ability of mosquitoes to transmit WNV (Reisen et al., 2006; Konrad et al., 2009). The time required for the virus to spread within the mosquito from the gut to the salivary glands, the extrinsic incubation period (EIP), decreases as the temperatures to which the mosquito is exposed after introduction to the virus increase (Reisen et al., 2006). If the EIP is completed while the mosquito continues to seek blood meals, the infected mosquito becomes capable of infecting other animals. Without enough heat and time, a mosquito which has taken an infected blood meal will not be able to transmit the virus. Thus, the local temperatures during the mosquito's feeding cycle are critical to determining whether a virus will spread.

Previously, we developed a geographical informa-

Corresponding author:

Sarah K. Konrad

University of Wyoming, Ecosystem Science and Management

Dept. 3354, Laramie, WY 82071, USA

Tel. +1 307766 2295; Fax +1 3077666403

E-mail: skonrad@uwyo.edu tion system (GIS)-based model, which summed degreeday (DD) temperatures over the duration of the vector feeding period to spatially and temporally evaluate the risk of mosquitoes transmitting arboviruses (Zou et al., 2007; Konrad et al., 2009, 2011; Konrad and Miller, 2012). The model was initially created to work with WNV transmitted by Culex tarsalis mosquitoes, but can be adapted for other arboviruses and mosquito species by changing a few model parameters. The difficulty in model development and calibration is in knowing how parameters change as a function of virus type and mosquito species.

Model parameters can be determined with captive mosquitoes or using observational data. Previous research has shown that model calibration can be successfully achieved using WNV-killed birds (Konrad et al., 2009; Schrag et al., 2011). Many regional vector control districts have active or historical surveillance programmes for WNV which involve the collection and testing of dead birds. Our approach exploits the position and timing of these collected birds, along with local temperatures leading up to the birds' death, the time it takes for birds to die post-infection, and estimates of both mosquito and bird travel distances. We successfully calibrated the model for WNV transmission in Santa Clara county, California (Konrad et al., 2009) and in the northern Rocky Mountains (Schrag et al., 2011), finding that similar parameters worked in both locations independent of mosquito species. Here, we test the calibrated model in eastern USA, using birds collected in South Carolina and Connecticut. 


\section{Materials and methods}

Daily maximum and minimum temperatures were downloaded from DAYMET (http://daymet.ornl.gov/; Thornton et al., 1997) on a 5-km grid for both South Carolina and Connecticut. DAYMET provides interpolated historical temperatures across the continental USA at a relatively fine grid that allows for high calibration accuracy. As DAYMET temperatures were only available through 2003, we limited our study to 2002-2003 in South Carolina and 2000-2003 in Connecticut (WNV first appeared in late summer 1999 in Connecticut and by mid-summer 2001 in South Carolina). Other inputs to the DD model include the length of the vector feeding period (defined as the time between the mosquito's first and last blood meal), the number of DDs necessary to reach EIP and the minimum transmission temperature. Previous research in the western USA provided baseline parameters from which we tested the model for South Carolina and Connecticut: initial model parameters were 76 DDs to reach EIP, a minimum transmission temperature of $14.3{ }^{\circ} \mathrm{C}$, and a 12 -day feeding period (Konrad et al., 2009).

The model sums the DD temperature for each grid square over a moving window the length of the feeding period, thus determining a DD sum for every point every day. If this sum is greater than the EIP, the model predicts transmission is possible; if less, transmission is not possible. The DD calculations follow Allen (1976) assuming a sinusoidal temperature variance between the daily maximum and minimum temperature. They are described in detail by Konrad et al. (2009, 2011) and Konrad and Miller (2012).

As with the Santa Clara county calibration (Konrad et al., 2009), we allowed for bird movement between the time of infection and death, mosquito movement during the feeding period, and the time between bird infection and death. In this study, we used American crows as they tend not to travel too far and die relatively quickly post-infection (McLean et al., 2001; Yaremich et al., 2004). All other collected birds were used for comparison with the crow dataset. The model was tested with the numbers that were successful in California: American crow death occur 4-8 days postinfection (McLean et al., 2001, Komar et al., 2003, Brault et al., 2004), crows travel up to $8 \mathrm{~km}$ in that period (Yaremych et al., 2004), and mosquitoes travel up to $2 \mathrm{~km}$ during their feeding period (Reisen and Lothrop, 1995). For analysis purposes, a temporal range of 4-10 days was selected (the extra 2 days allowing for time between the crow's death and its collection). The mosquito and the crow ranges combine for a maximum allowable travel distance of $10 \mathrm{~km}$, measured from the site at which the dead crow was collected. Thus, if a dead crow is found within $10 \mathrm{~km}$ of a predicted risk location, and that location was at risk at some point during the 4-10 days before the crow was found, then the crow's death is considered to be successfully accounted for by the model. Conversely, if the model predicts no transmission risk within a radius of $10 \mathrm{~km}$ around the dead crow during the 4-10 days before the collection date, then the crow's death is considered to be unaccounted for by

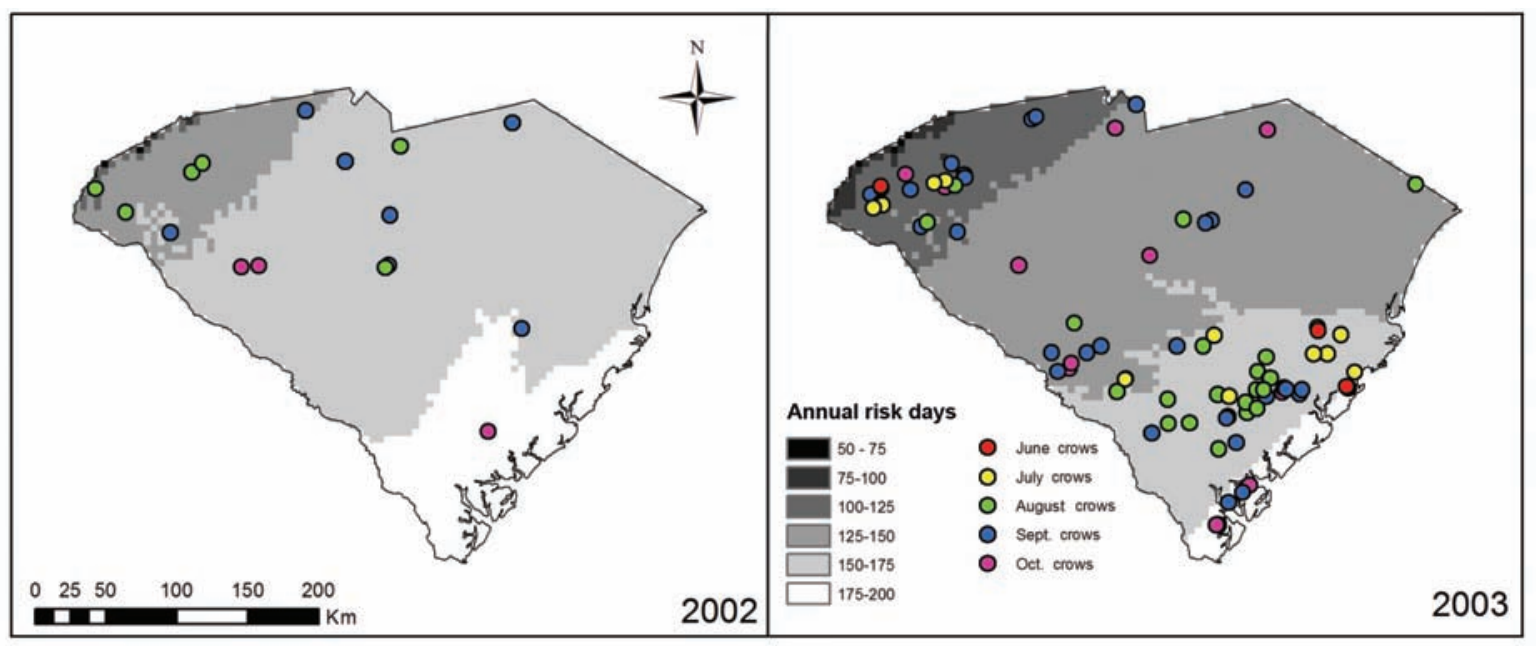

Fig. 1. WNV-positive crows collected in South Carolina in 2002 and 2003. Background shows the total number of predicted WNV-transmission risk days for the given year. 
the model.

Results and discussion

Fig. 1 shows the locations of WNV-positive crows collected in South Carolina in 2002 and 2003 against a backdrop of the number of annual risk days determined for each grid square over the course of the year (days in which temperature-limited transmission could occur). The year 2002 was overall a warmer year than 2003; however, fewer WNV-positive crows were collected. In both years, the southern part of the state experienced a greater number of risk days than the north-western portion, but there does not appear to be any particular correlation between where and when the crows were found. Fig. 2 shows the locations of all WNV-positive birds including crows collected in
Connecticut in 2000-2003 against a backdrop of predicted annual risk days. As in South Carolina, 2003 was generally cooler than 2002 in Connecticut, with 2001 being cooler yet, and 2000 the coolest year of the four. Again, there is no obvious correlation between where and when the birds were found with respect to temperature trends across the state.

Table 1 summarises the WNV-positive bird data for both states, showing the total numbers of all birds and crows, and the percentage of each that are accounted for by the temperature-based transmission risk model using the California parameters. As we found in California, the model worked well to describe the bird deaths at the start of the risk "season" as temperatures warm into summer but did not successfully predict the deaths towards the end of the season when autumn

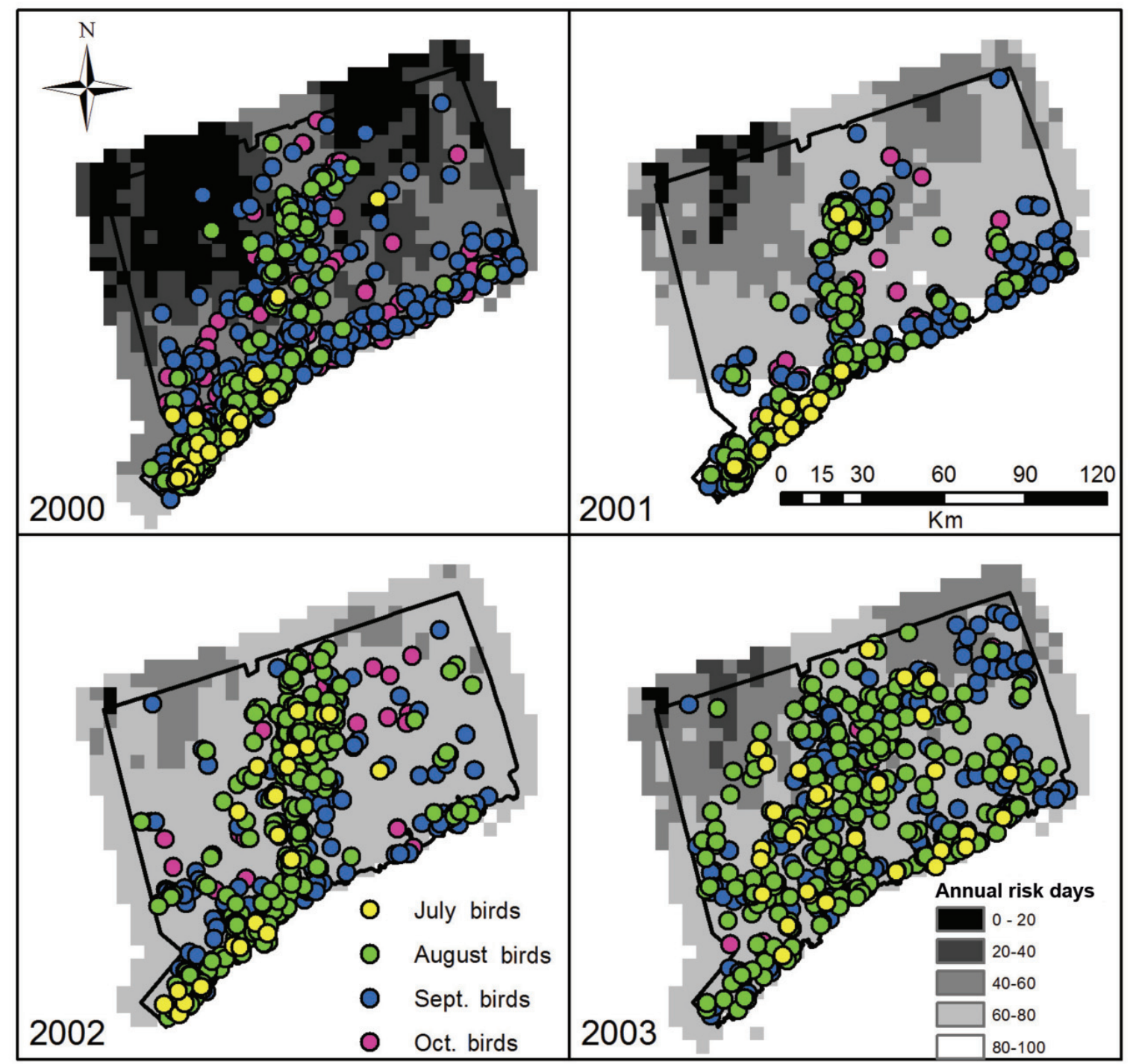

Fig. 2. WNV-positive birds (all species) collected in Connecticut from 2000-2003. Background shows the total number of predicted WNV-transmission risk days for the given year. 
Table 1. Comparison of WNV-killed bird data. The total number of WNV-positive birds (including crows) and crows collected, the percent of these that are accounted for by the model, and the number of birds collected before the model-predicted onset of the transmission season are shown. California and Montana/Wyoming data from Konrad et al. (2009) and Schrag et al. (2011), respectively.

\begin{tabular}{|c|c|c|c|c|c|c|}
\hline \multirow[b]{2}{*}{ Location and year } & \multicolumn{3}{|c|}{ All birds } & \multicolumn{3}{|c|}{ All crows } \\
\hline & $\begin{array}{c}\text { No. WNV } \\
\text { positive }\end{array}$ & $\begin{array}{l}\text { Percent } \\
\text { fit model }\end{array}$ & $\begin{array}{l}\text { No. early } \\
\text { season not fit }\end{array}$ & $\begin{array}{c}\text { No. WNV } \\
\text { positive }\end{array}$ & $\begin{array}{l}\text { Percent } \\
\text { fit model }\end{array}$ & $\begin{array}{c}\text { No. early } \\
\text { season not fit }\end{array}$ \\
\hline South Carolina, 2002 & 52 & 87 & 0 & 20 & 95 & 0 \\
\hline South Carolina, 2003 & 277 & 91 & 1 & 93 & 95 & 0 \\
\hline Connecticut, 2000 & 1085 & 62 & 0 & 1085 & 62 & 0 \\
\hline Connecticut, 2001 & 441 & 79 & 1 & 419 & 79 & 1 \\
\hline Connecticut, 2002 & 528 & 86 & 6 & 501 & 86 & 6 \\
\hline Connecticut, 2003 & 514 & 86 & 2 & 435 & 88 & 2 \\
\hline Santa Clara county, 2005 & - & - & - & 122 & 90 & 2 \\
\hline Santa Clara county, 2006 & - & - & - & 217 & 94 & 0 \\
\hline Montana/Wyoming, 2003-2007 & 25 & 100 & 0 & - & - & - \\
\hline
\end{tabular}

temperatures were often too low to predict transmission. However, birds were still dying from WNV (Fig. 3). These late-season deaths can likely be attributed to lateral virus transmission through direct contact or faecal contamination (Dawson et al., 2007, Hartemink et al., 2008), which are not accounted for in our model. The model does a particularly poor job of accounting for the late-season deaths in Connecticut (12-38\%). It is unclear why this would be the case. One possibility is that Connecticut has higher bird density than the other states (more dead birds were collected in Connecticut than either South Carolina or California, even though Connecticut is the smallest state of the three), creating the opportunity for more lateral virus transmission.

Because of the importance of both informing the public and appropriately controlling mosquitos at the onset of WNV transmission, it is more important that the model accurately predict early-season bird deaths. In South Carolina, only one early-season bird death

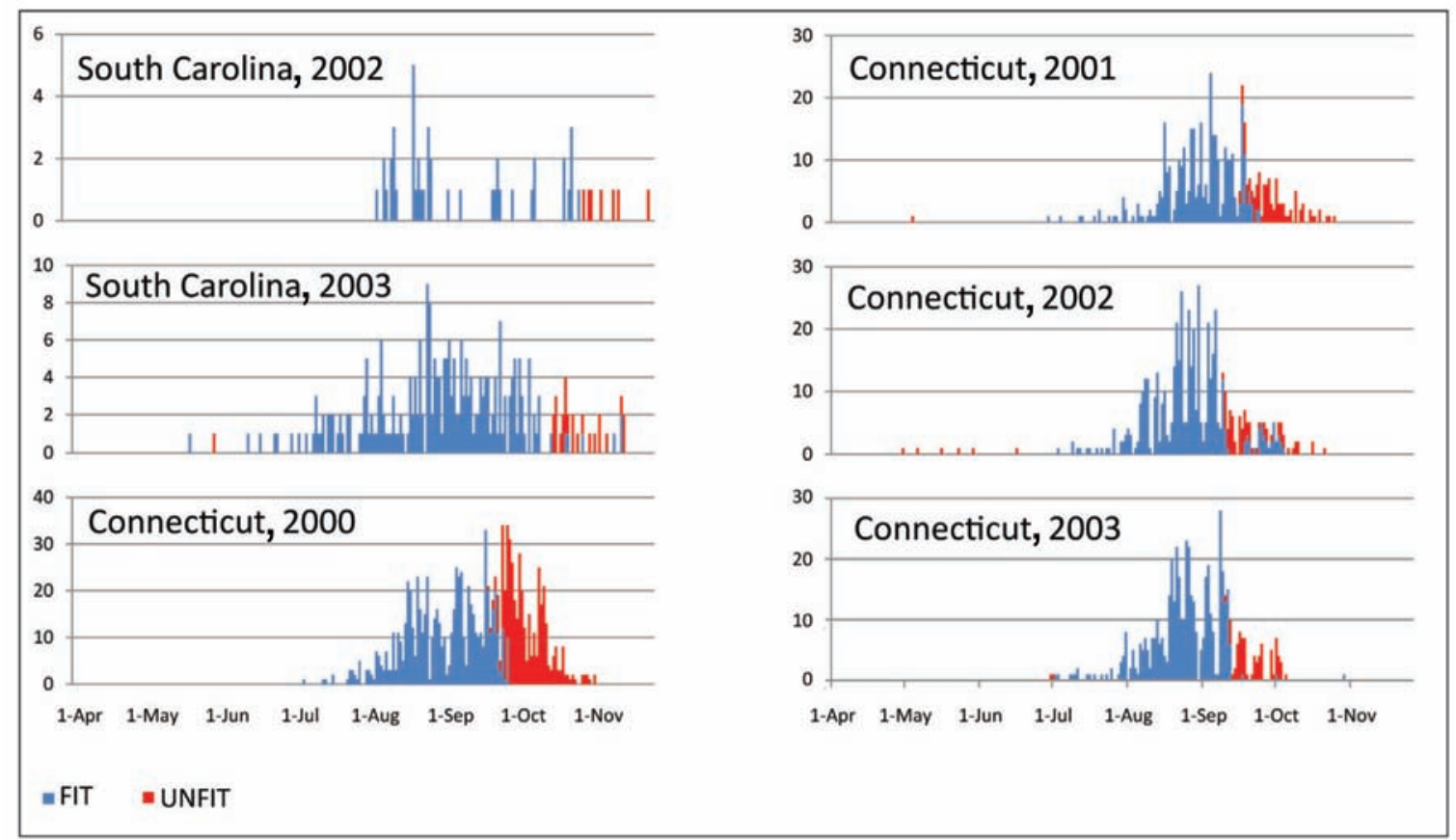

Fig. 3. All birds plotted against collection date. Blue signifies that the bird's death from WNV was accounted for by the calibrated model; red signifies that it was not. Note that the vertical scale denoting the number of birds collected varies between states and years. 
(and no crow deaths) was not correctly predicted by the model $(0.3 \%$ of the total birds collected). In Connecticut, a total of nine bird (all crows) early-season deaths were not predicted (also $0.3 \%$ of the total birds collected). For comparison, Table 1 includes data from two previous studies: Santa Clara county, California (Konrad et al., 2009) and northern Wyoming/southern Montana (Schrag et al., 2011). In California, two early-season crow deaths were missed out of 339 collected (0.5\%), and in Wyoming/ Montana, no early season deaths failed to be predicted.

The parameters originally derived in California predict the transmission risk equally well in various locations across the USA, including the Rocky Mountain region (Wyoming/Montana), the Northeast (Connecticut) and the Southeast (South Carolina). Therefore, the local species of mosquito, or variations in virus genotype in the region, does not appear to be of primary importance, as the most likely vector in Santa Clara county is the hybrid Culex pipiens/Cx. quinquefasciatus, in Montana/Wyoming Cx. tarsalis, in Connecticut Cx. pipiens (Andreadis et al., 2004), and in South Carolina Cx. quinquefasciatus and $C x$. nigripalpus (Rutledge et al., 2003; Godsey et al., 2005). The variance of the percentage of all bird species versus crows that fit the model (Table 1 ) is primarily due to the late season deaths, for which there are alternate transmission mechanisms likely at work suggesting that other birds can be effectively used to test the model in new locations.

Our hope is that this model, which effectively predicts the onset of the WNV risk season across the USA, will be used by local vector control districts to help determine the timing and extent of vector mitigation efforts. To this end, we have created a free, online version of the model that automatically updates daily risk forecasts (Konrad et al., 2012).

\section{Acknowledgements}

This project was funded by the United States Department of Agriculture specific cooperative agreement \#5410-32000-01415. We are grateful to Dr. Randall Nelson of the Connecticut Department of Health and Dr. Chris Evans of the South Carolina Department of Health and Environmental Control for providing the bird data.

\section{References}

Allen JC, 1976. A modified sine wave method for calculating degree-days. Environ Entomol 5, 388-396.

Andreadis TG, Anderson JF, Vossbrinck CR, Main AJ, 2004.
Epidemiology of West Nile virus in Connecticut: a five-year analysis of mosquito data, 1999-2003. Vector Borne Zoonotic Dis 4, 360-378.

Brault AC, Langevin SA, Bowen RA, Panella NA, Biggerstaff BJ, Miller BR, Komar N, 2004. Differential virulence of West Nile strains for American crows. Emerg Infect Dis 10, 2161-2168.

Dawson JR, Stone WB, Ebel GD, Young DS, Galinski DS, Pensabene JP, Franke MA, Eidson M, Kramer LD, 2007. Crow deaths caused by West Nile virus during winter. Emerg Infect Dis 13, 1912-1914.

Enserink M, 2002. West Nile's surprisingly swift continental sweep. Science 297, 1988-1989.

Godsey MS, Blackmore MS, Panella NA, Burkhalter K, Gottfried K, Halsey LA, Rutledge R, Langevin SA, Gates R, Lamonte KM, Lambert A, Lanciotti RS, Blackmore CGM, Loyless T, Stark L, Oliveri R, Conti L, Komar N, 2005. West Nile virus epizootiology in the southeastern United States, 2001. Vector Borne Zoonotic Dis 5, 82-89.

Hartemink NA, Davis SA, Reiter P, Hubálek Z, Heesterbeek JAP, 2008. Importance of bird-to-bird transmission for the establishment of West Nile virus. Vector Borne Zoonotic Dis 7, $575-584$.

Hayes CG, 1989. West Nile fever. In: The arboviruses: epidemiology and ecology (Monath TP, ed). CRC Press 5, 59-88.

Komar N, Langevin S, Hinten S, Nemeth N, Edwards E, Hettler D, Davis B, Bowen R, Bunning M, 2003. Experimental infection of North American birds with the New York 1999 strain of West Nile virus. Emerg Infect Dis 9, 311-322.

Konrad SK, Miller SN, 2012. A temperature-limited assessment of the risk of Rift Valley fever transmission and establishment in the continental United States. Geospat Health 6, 160-170.

Konrad SK, Miller SN, Reeves WK, 2011. A spatially explicit degree-day model of Rift Valley fever transmission risk in the continental United States. GeoJournal 76, 257-266.

Konrad SK, Miller SN, Reeves WK, Tietze NS, 2009. Spatially explicit West Nile virus risk modeling in Santa Clara county, CA. Vector Borne Zoonotic Dis 9, 267-274.

Konrad SK, Zou L, Miller SN, 2012. A geographical information system-based web model of arbovirus transmission risk in the continental United States of America. Geospat Health 7, 157-159.

McLean RG, Ubico SR, Docherty DE, Hansen WR, Sileo L, McNamara TS, 2001. West Nile virus transmission and ecology in birds. Ann N Y Acad Sci 951, 54-57.

Reisen WK, Fang Y, Martinez VM, 2006. Effects of temperature on the transmission of West Nile virus by Culex tarsalis (Diptera: Culicidae). J Med Entomol 43, 309-317.

Reisen WK, Lothrop HD, 1995. Population ecology and dispersal of Culex tarsalis (Diptera: Culicidae) in the Coachella Valley of California. J Med Entomol 32, 490-502.

Rutledge CR, Day JF, Lord CC, Stark LM, Tabachnick WJ, 2003. West Nile virus infection rates in Culex nigripalpus 
(Diptera: Culicidae) do not reflect transmission rates in Florida. J Med Entomol 40, 253-258.

Schrag AM, Konrad SK, Miller SN, Walker BL, Forrest SC, 2011. Climate-change impacts on sagebrush habitat and West Nile virus transmission risk and conservation implications for greater sage grouse. GeoJournal 76, 561-575.

Thornton PE, Running SW, White MA, 1997. Generating surfaces of daily meteorology variables over large regions of com- plex terrain. J Hydrol 190, 214-251.

Yaremych SA, Novak RJ, Raim AJ, Mankin PC, Warner RE, 2004. Home range and habitat use by American crows in relation to transmission of West Nile virus. Wilson Bull 116, 232239.

Zou L, Miller SN, Schmidtmann ET, 2007. A GIS tool to estimate West Nile virus risk based on a degree-day model. Environ Monit Assess 129, 413-420. 